\title{
Cikkismertetés: Hogyan növelhetjük egyszerű változtatásokkal a gyermekek iskolai gyümölcsfogyasztását?
}

\author{
Article review: How to increase children's fruit consumption with simple \\ changes in school?
}

$\begin{array}{ll}\text { Ismertető: } & \text { Devosa Iván } \square \\ & \text { Neumann János Egyetem Pedagógusképző Kar, Egészségtudományi és } \\ & \text { Egészégfejlesztési Kutatócsoport }\end{array}$

Ismertetett cikk: Marcano-Olivier M, Pearson R, Ruparell A, et al. A low-cost Behavioural Nudge and choice architecture intervention targeting school lunches increases children's consumption of fruit: a cluster randomised trial Int J Behav Nutr Phys Act. 2019 Feb 13;16(1):20 doi: $\underline{10.1186 / s 12966-019-0773-x}$

Beküldve: $\quad$ 2019. 03. 08.

doi: $\quad$ 10.24365/ef.v60i2.440

Kulcsszavak: gyümölcsfogyasztás; iskolai ebéd; egészséges táplálkozás; gyermekek

Keywords: fruit consumption; school lunch; healthy eating; children

\section{HÁTTÉR}

A felmérések szerint a legtöbb gyermek zöldség- és gyümölcsfogyasztása elmarad az étrendi ajánlásoktól. A szerzők egyszerű, alacsony költségvetésú magatartástudományi kísérlettel kívánták ösztönözi a gyermekeket arra, hogy az iskolai étkezdében több zöldséget és gyümölcsöt fogyasszanak ebédre.

\section{MÓDSZER}

A vizsgálathoz véletlenszerűen választottak ki négy nagy-britanniai általános iskolát, majd az előzetes adatgyüjtés iskolánként két-két napig tartott. Ezt követően a négy iskola közül kettőben megváltoztatták az iskolai étkezdék által kínált ételek tálalási módját. A két kísérleti iskolában az ételek új tálalási módját a kutatás végső szakasza előtt három héttel vezették be. A kontrolliskolákban ez idő alatt nem változtattak semmit sem az étkezdékben, sem a konyhai személyzet viselkedését illetően.
A kutatás az alábbi változtatásokat foglalta magába a két kísérleti általános iskolában:

- A zöldségeket és gyümölcsöket színes poszterekkel, rajzfilmfigurákkal reklámozták.

- A zöldségek és gyümölcsök figyelemfelkeltő, mókás neveket kaptak.

- A zöldségeket és gyümölcsöket grafikailag vonzó címkével látták el.

- A zöldségek és gyümölcsök jobban láthatóvá és elérhetővé váltak a gyermekek számára, a gyümölcsöket egy egész darab helyett fogyasztásra kész darabokban tálalták.

- A zöldségek és gyümölcsök ajánlása megváltozott: egy adagnyi zöldség fogyasztását ajánlották az előétel, illetve a keményítőtartalmú köret előtt, valamint egy adagnyi gyümölcsöt kínáltak a desszert előtt.

- Az étkezdék személyzetét kérték, hogy bátorítsák a diákokat arra, hogy az ebédjük részeként zöldséget és gyümölcsöt is válasszanak. 
A háromhetes időszak után az iskolákban ismételten két napig gyüjtötték az adatokat a diákok zöldségés gyümölcsfogyasztásának, az elfogyasztott ételek C-vitamin-, rost-, valamint cukorbevitelének és teljes kalóriatartalmának meghatározásához. Ehhez mérési módszerként fényképet készítettek a gyermekek által választott ételekről ebéd előtt és étkezés után a tényleges táplálékbevitel meghatározására. A vizsgálatban összesen 176 általános iskolás vett részt, közülük 86-an a zöldség- és gyümölcsfogyasztás növelését célzó két iskolában tanultak, 90 diák pedig a két kontrolliskola tanulója volt.

\section{EREDMÉNYEK}

A résztvevő iskolákban a gyermekek 46,5\%-nak jelentősen növekedett a gyümölcsfogyasztása, valamint a C-vitamin- és rostbevitelében is pozitív irányú változás volt észlelhető. A gyermekek nagy részénél tapasztalták a gyümölcsfogyasztás mértékének növekedését attól függetlenül, hogy az a kísérlet előtt mekkora volt. A zöldségfogyasztás mértékében azonban a beavatkozás ellenére sem tudtak változást megfigyelni. A kontrollcsoportot alkotó iskolákban ezzel ellentétben nem tapasztaltak jelentős változást a gyermekek étkezési és ételválasztási szokásaiban.

\section{KÖVETKEZTETÉSEK}

Ezek az eredmények az elsők között mutatnak arra, hogy az iskolai étkezdék kínálatának mérsékelt változtatásával és viselkedésösztönzők bevonásával jelentősen növelni lehet a gyermekek gyümölcsfogyasztását. Marcano-Olivier és mtsai megállapítása szerint mindez hatással lehet az egészséges táplálkozást elősegítő nemzeti és nemzetközi stratégiák kidolgozására is.

\section{TANULSÁGOK A HAZAI SZAKEMBEREK SZÁMÁRA}

A kutatás különös jelentősége az volt, hogy bebizonyosodott, az iskolai étkezdék kínálatának szinte költségmentes átalakításával a diákok táplálkozása pozitív irányba befolyásolható. A tanulmányból látszik, hogy a kínálatban már korábban is szereplő ételek áthelyezésével, elérhetőbbé tételével, valamint grafikailag vonzóbb címkével megjelenítve, hívogató szlogennel „megszemélyesítve” jobban felkeltik a gyermekek érdeklődését. Az iskolai étkeztetés megújításán dolgozó hazai szakembereknek éppen ezért érdemes lenne megfontolni, hogy az étkezdékben, büfékben kihelyezett áruk láthatóságát, elérhetőségét is célszerű lenne szabályozni, hiszen itt nem átlagos kereskedelmi egységről van szó, hanem a gyermekek egészséges életmódra nevelésének egyik látens eszközéről.

\section{KÖSZÖNETNYILVÁNÍTÁS}

Köszönettel tartozunk a publikálás támogatásáért, amely az EFOP-3.6.1-16-2016-00006 „A kutatási potenciál fejlesztése és bővitése a Neumann János Egyetemen" pályázat keretében valósult meg. A projekt a Magyar Állam és az Európai Unió támogatásával, az Európai Szociális Alap társfinanszírozásával, a Széchenyi 2020 program keretében valósul meg. 